\title{
Characterization of Diarrheagenic Escherichia coli Isolated in Organic Waste Products (Cattle Fecal Matter, Manure and, Slurry) from Cattle's Markets in Ouagadougou, Burkina Faso
}

\author{
Evariste Bako ${ }^{1, *}$, Assèta Kagambèga ${ }^{1,2}$, Kuan Abdoulaye Traore ${ }^{1}$, Touwendsida Serge Bagre ${ }^{1}$, \\ Hadiza Bawa Ibrahim ${ }^{1}$, Soutongnooma Caroline Bouda ${ }^{1}$, Isidore Juste Ouindgueta Bonkoungou ${ }^{1}$, \\ Saidou Kaboré ${ }^{1,3}$, Cheikna Zongo ${ }^{4}$, Alfred Sababenejo Traore ${ }^{5}$ and Nicolas Barro ${ }^{1}$ \\ 1 Laboratoire de Biologie Moléculaire d'Epidémiologie et de Surveillance des Bactéries \\ et Virus Transmis par les Aliments (LaBESTA), Centre de Recherche en Sciences Biologiques, \\ Alimentaires et Nutritionnelles (CRSBAN), Université Ouaga I Prof Joseph KI-ZERBO, \\ 03 BP 7021 Ouagadougou 03, Burkina Faso; kagambega.asseta@gmail.com (A.K.); \\ kuanbauer@yahoo.fr (K.A.T.); sergebagre@gmail.com (T.S.B.); hadizabawa@yahoo.fr (H.B.I.); \\ boudacaroline@gmail.com (S.C.B.); ouindgueta@gmail.com (I.J.O.B.); saidoukabore@gmail.com (S.K.); \\ barronicolas@yahoo.fr (N.B.) \\ 2 Institut de Sciences, 01 BP 1757 Ouagadougou 01, Burkina Faso \\ 3 Direction de la Nutrition, Ministère de la Santé, 03 BP 7068 Ouagadougou 03, Burkina Faso \\ 4 Laboratoire de Biochimie et d'Immunologie Appliquée (LABIA), Centre de Recherche en Sciences \\ Biologiques Alimentaires et Nutritionnelles (CRSBAN), Université Ouaga I Professeur Joseph KI-ZERBO, \\ 03 BP 7131 Ouagadougou 03, Burkina Faso; zcheik@yahoo.fr \\ 5 Centre de Recherche en Sciences Biologiques Alimentaires et Nutritionnelles (CRSBAN), Université Ouaga I \\ Professeur Joseph KI-ZERBO, 03 BP 7131 Ouagadougou 03, Burkina Faso; astraore@univ-ouaga.bf \\ * Correspondence: evaristebako80@gmail.com; Tel.: +226-7538-1699
}

Received: 2 August 2017; Accepted: 14 September 2017; Published: 22 September 2017

\begin{abstract}
Cattle farming can promote diarrheal disease transmission through waste, effluents or cattle fecal matter. The study aims to characterize the diarrheagenic Escherichia coli (DEC) isolated from cattle feces, manure in the composting process and slurry, collected from four cattle markets in Ouagadougou. A total of 585 samples (340 cattle feces, 200 slurries and 45 manures in the composting process) were collected from the four cattle markets between May 2015 and May 2016. A multiplex Polymerase Chain Reaction (PCR), namely 16-plex PCR, was used to screen simultaneously the virulence genes specific for shiga toxin-producing E. coli (STEC), enteropathogenic E. coli (EPEC), enterotoxigenic E. coli (ETEC), enteroinvasive E. coli (EIEC) and enteroaggregative E. coli (EAEC). DEC was detected in $10.76 \%$ of samples. ETEC was the most prevalent $(9.91 \%)$. STEC and EAEC have been observed with the same rate $(0.51 \%)$. ETEC were detected in $12.64 \%$ of cattle feces, in $6.66 \%$ of manure in the composting process and in $5 \%$ of slurry. STEC were detected in $0.58 \%$ of cattle feces and in $2.22 \%$ of manure in the composting process. EAEC was detected only in $1 \%$ of slurry and in $2.22 \%$ of manure in the composting process. ETEC strains were identified based on estIa gene and/or estIb gene and/or elt gene amplification. Of the 58 ETEC, $10.34 \%$ contained ast $A, 17.24 \%$ contained elt, $3.44 \%$ contained estIa and $79.31 \%$ contained estIb. The two positive EAEC strains contained only the $\operatorname{aggR}$ gene, and the third was positive only for the pic gene. The results show that effluent from cattle markets could contribute to the spreading of DEC in the environment in Burkina Faso.
\end{abstract}

Keywords: manure; cattle fecal matter; STEC; ETEC; EAEC; slurries; cattle market; diarrheal diseases; environment sanitation; public health 


\section{Introduction}

Fecal contamination is one of the primary contributory factors to the persistence of diarrheagenic pathogens in the environment and contributes to the contamination of food crops and water sources. Intensive cattle farming through cattle fecal matter and effluents contributes to the spreading of these diarrheagenic pathogens in the environment [1].

Healthy asymptomatic food animals may carry zoonotic pathogens and represent a principal reservoir of diarrheagenic Escherichia coli (DEC), which may enter the food chain via the weak points in the hygiene practices of the slaughter process $[2,3]$.

Traditionally, E. coli has been considered a harmless, commensal bacterium. However, several diarrheagenic pathotypes have been recognized based on virulence properties and the mechanisms of pathogenicity [4]. The five main pathotypes of DEC are enteroinvasive E. coli (EIEC), enteropathogenic E. coli (EPEC), shiga toxin-producing E. coli (STEC), enterotoxigenic E. coli (ETEC) and enteroaggregative E. coli (EAEC) $[5,6]$. Other authors call these organisms "enteroaggregative, verotoxin-producing E. coli." STEC produces toxin (shiga toxin) encoded by the $s t x_{1}$ or $s t x_{2}$ genes or their variants. In addition to shiga toxin (stx) gene(s), STEC strains often carry the eae gene, encoding the adherence factor intimin. They have also additional virulence genes such as enterohemolysin (EHEC-hly) [7]. STEC can cause gastroenteritis, which may be complicated by hemorrhagic colitis or hemolytic-uremic syndrome (HUS), the main cause of acute renal failure in children [8]. EPEC produces characteristic histopathology known as attaching and effacing (A/E) on intestinal cells [9] EPEC is further divided into two subtypes, typical (tEPEC) and atypical (aEPEC), depending on the presence or absence of the EPEC adherence factor (EAF) plasmid and the $b f p B$ gene [6,9]. Strains of aEPEC occur most frequently in developed countries, whereas tEPEC is the leading cause of infantile diarrhea in developing countries [10]. ETEC produces heat-labile (LT) and or heat-stable (ST) enterotoxin and is an important cause of diarrhea in infants and travelers, particularly in developing countries [11]. EIEC is associated with invasive, bloody diarrhea resembling that caused by Shigella spp. Invasion is mediated by the genes located in virulence plasmid pINV encoding, for example Ipa proteins and their transcription regulator invE [6,12]. EAEC harbors the mechanism for the aggregative-adherence pattern mediated by aggregative adhesive fimbriae. It is increasingly recognized as a diarrheal pathogen in developing countries [13].

Burkina Faso is a developing country where cattle farming contributes significantly to the economy [14]. Some localized areas serve as cattle markets to help breeders to maximize their profits [15]. Large quantities of waste (fecal matter, manure and manure slurry (liquid waste)) from these markets are directly discharge in the environment without any treatment note far residential areas or applied as fertilizer to land used for silage, grazing or cultivation [16-18], what often cause direct contact between humans and these cattle organic waste.

Previous study conducted in Burkina Faso on food animals concluded that cattle are a reservoir for several DEC [19]. Available study showed that DEC are the most predominant pathogens associated with acute diarrhea in children in Burkina Faso [20-22].

Despite significant investments in the prevention of diarrheal-related morbidity and mortality, diarrhea remains one of the leading sources of under-five years of age mortality (U5M) worldwide, leading to more than 2100 U5M deaths daily [23]. Among these deaths, more than three-quarters occur mostly in poor and less developed countries of the world [24] with $42 \%$ in Sub-Saharan Africa [25].

About $88 \%$ of diarrhea-associated deaths are attributable to a lack of safe water, inadequate sanitation and insufficient hygiene [23].

Unless appropriately processed, manure is a potential biohazard capable of transmitting infective agents, including DEC, to both humans and animals $[16,17,26,27]$. Frequently, DEC is released into the environment through cattle manure [28]. Pathogens may be transported via sediments to vast geographical regions resulting in an increased prevalence in the environment $[29,30]$. However, the dynamics and routes of the spread of pathogens in farm environments are also poorly understood. 
The aim of this study was to characterize diarrheagenic E. coli (DEC) strains isolated from cattle feces, manure in the composting process and slurry purchased at four cattle markets located in Ouagadougou, and thus, it provides useful background information to improve manure management practices in urban and peri urban areas for future environmental safety and public health surveillance programs.

\section{Materials and Methods}

\subsection{Study Design and Sampling Sites}

The study was carried out on 4 cattle markets. These markets are respectively the cattle market of Kilwin $\left(12^{\circ} 23^{\prime} 367^{\prime \prime} \mathrm{N} ; 1^{\circ} 35^{\prime} 019^{\prime \prime} \mathrm{W}\right)$, the cattle market of Sougre Nooma $\left(12^{\circ} 23^{\prime} 540^{\prime \prime} \mathrm{N} ; 1^{\circ} 31^{\prime} 836^{\prime \prime} \mathrm{W}\right)$, the cattle market of Ouaga Inter $\left(12^{\circ} 20^{\prime} 156^{\prime \prime} \mathrm{N} ; 1^{\circ} 30^{\prime} 995^{\prime \prime} \mathrm{W}\right)$ and the cattle market of Kouritenga $\left(12^{\circ} 20^{\prime} 078^{\prime \prime} \mathrm{N} ; 1^{\circ} 32^{\prime} 623^{\prime \prime} \mathrm{W}\right)$ (Figure 1). This choice was motivated by the fact that these markets are terminals or consumer markets, where the confluence of a significant number of animals is remarkable. The typology of these markets means that they are most often located in the city near residential areas and certain surface waters such as dams.

A total of 585 samples of cattle feces $(n=340)$, slurry $(n=200)$ and manure in the composting process $(n=45)$ were collected, between May 2015 and May 2016. Slurry was a mixture of feces, urine, water and straw.

Briefly, $200 \mathrm{~g}$ of samples (cattle fecal matter, manure in the composting process, slurry) were collected and placed in sterile plastics bags. The samples of cattle feces were collected freshly when the animal defecated, and slurry and manure in the composting process were collected directly from the soil of the sampling site, using a sterile spatula. The samples were transported to the laboratory under appropriate refrigerated conditions and processed within $2 \mathrm{~h}$ after collection.

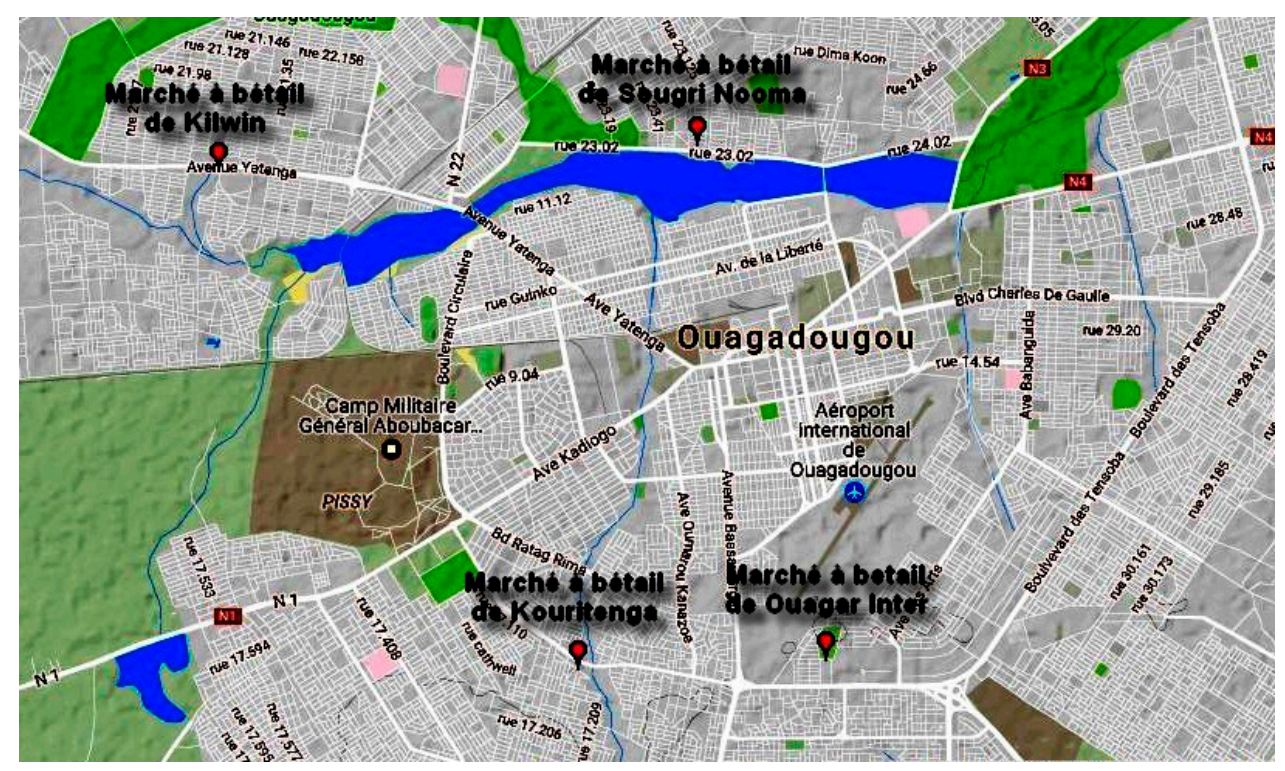

Figure 1. Map of Ouagadougou with the sampling sites. Source: Google Map.

\subsection{Escherichia coli Isolation}

The isolation of Escherichia coli strains was carried out according to the guidelines of ISO 4832: 1951 (F). Briefly, $25 \mathrm{~g}$ of each sample were added into $225 \mathrm{~mL}$ of buffered peptone water (BPW) (Liofilchem, Teramo, Italy) and homogenized using a stomacher (400 Circulator, Seward, London, UK). This step is followed by cascade dilution, which could often go up to $10^{-7}$ dilution depending on the type of sample. A loopful of these diluents was streaked onto sorbitol MacConkey agar (Liofilchem, 
Teramo, Italy) and incubated at $44{ }^{\circ} \mathrm{C}$ overnight. After incubation, suspected colonies were confirmed by biochemical tests including indole, methyl red, Voges-Proskauer and citrate [31]. The confirmed colonies were conserved in tubes with $1 \mathrm{~mL}$ brain heart infusion broth containing $15 \%(v / v)$ glycerol for further analysis at $4{ }^{\circ} \mathrm{C}$.

\subsection{Detection of Diarrheagenic Escherichia coli}

DEC were identified by multiplex-PCR [32]. The fragments of 16 virulence genes were amplified with specific primers (Table 1) as previously described [33]. For DNA extraction, a loopful of bacteria growing on sorbitol MacConkey agar was transferred to an Eppendorf tube with $250 \mu \mathrm{L}$ water. The mixture was boiled for $10 \mathrm{~min}$ and centrifuged for $1 \mathrm{~min}$ at $13,000 \mathrm{~g}$, and the supernatant was analyzed in the PCR reactions. For PCR, $1 \mu \mathrm{L}$ of the supernatant (DNA) was added to $19 \mu \mathrm{L}$ reaction mixture containing $4 \mu \mathrm{L} 5 \times$ Master Mix (Solis biodyne, Tartu, Estonia), $13 \mu \mathrm{L}$ water and PCR primers ( $1 \mu \mathrm{L}$ Jenni Mix, $1 \mu \mathrm{L}$ Muller Mix at the concentrations listed in Table 1$)$. The cycling conditions used in the thermal cycler (TC-412) (Bibby Scientific, Lille, France) were $98^{\circ} \mathrm{C}$ for $30 \mathrm{~s}, 35$ cycles of $98^{\circ} \mathrm{C}$ for $30 \mathrm{~s}$, $62{ }^{\circ} \mathrm{C}$ for $60 \mathrm{~s}$ and $72{ }^{\circ} \mathrm{C}$ for $90 \mathrm{~s}$, with a final extension at $72{ }^{\circ} \mathrm{C}$ for $10 \mathrm{~min}$. Amplified DNA fragments were separated by agarose gel electrophoresis ( $\%$ weight/volume), stained with ethidium bromide and visualized under UV light. Reference strains EPEC RH 4283 (E 2348/69, [34]), ETEC RH4266 (ATCC 35401), STEC RH 4270 (ATCC 43895), EIEC RH 6647 (145-46-215; Statens Serum Institute, Copenhagen, Denmark), EAEC IH 56822 (patient isolate [35]) and sterile distilled water were included in each PCR run. The criteria for the determination of a DEC were as follows: for EPEC, the presence of $e a e A$ and $e s c V$ and possible additional genes ent and $b f p B$, and the absence of $b f p B$ indicated atypical EPEC; for ETEC, the presence of elt and/or estIa or estIb; for STEC, the presence of stx $x_{1}$ and or stx 2 and possible additional genes eae, escV, ent and EHEC-hly; for EIEC, the presence of $i n v E$ and ipaH; for EAEC, the presence of pic and/or aggR. The gene uidA was used as a general marker for E. coli. The gene $a s t A$ was not specific for a certain pathogroup, so it was not used in the final analysis.

Table 1. 16-Plex PCR primers and the virulence genes detected.

\begin{tabular}{|c|c|c|c|c|c|}
\hline Pathotypes & Target Genes & Primer Sequence $\left(5^{\prime}-3^{\prime}\right)$ & $\begin{array}{l}\text { Product } \\
\text { Size (bp) }\end{array}$ & $\begin{array}{l}\text { Concentration } \\
(\mu \mathrm{M})\end{array}$ & References \\
\hline \multirow{3}{*}{ STEC, EPEC } & $e a e A$ & $\begin{array}{l}\text { eae-F: TCAATGCAGTTCCGTTATCAGTT } \\
\text { eae-R: GTAAAGTCCGTTACCCCAACCTG }\end{array}$ & 482 & 0.1 & [36] \\
\hline & $\operatorname{esc} V$ & $\begin{array}{l}\text { MP3-escV-F: ATTCTGGCTCTCTTCTTCTTTATGGCTG } \\
\text { MP3-escV-R: CGTCCCCTTTTACAAACTTCATCGC }\end{array}$ & 544 & 0.4 & [32] \\
\hline & ent & $\begin{array}{l}\text { ent-F: TGGGCTAAAAGAAGACACACTG } \\
\text { ent-R: CAAGCATCCTGATTATCTCACC }\end{array}$ & 629 & 0.4 & [32] \\
\hline Typical EPEC & $b f p B$ & $\begin{array}{l}\text { MP3-bfpB-F: GACACCTCATTGCTGAAGTCG } \\
\text { MP3-bfpB-R: CCAGAACACCTCCGTTATGC }\end{array}$ & 910 & 0.1 & [32] \\
\hline \multirow{3}{*}{ STEC } & EHEC-hly & $\begin{array}{l}\text { hlyEHEC-F: TTCTGGGAAACAGTGACGCACATA } \\
\text { hlyEHEC-R: TCACCGATCTTCTCATCCCAATG }\end{array}$ & 688 & 0.1 & [33] \\
\hline & $s t x_{1}$ & $\begin{array}{l}\text { MP4-stx1A F: CGATGTTACGGTTTGTTACTGTGACAGC } \\
\text { MP4-stx1A-R: AATGCCACGCTTCCCAGAATTG }\end{array}$ & 244 & 0.2 & [32] \\
\hline & $s t x_{2}$ & $\begin{array}{l}\text { MP3-stx2A-F: GTTTTGACCATCTTCGTCTGATTATTGAG } \\
\text { MP3-stx2A-R: AGCGTAAGGCTTCTGCTGTGAC }\end{array}$ & 324 & 0.4 & [32] \\
\hline \multirow{2}{*}{ EIEC } & $i p a H$ & $\begin{array}{l}\text { ipaH-F: GAAAACCCTCCTGGTCCATCAGG } \\
\text { ipaH-R: GCCGGTCAGCCACCCTCTGAGAGTAC }\end{array}$ & 437 & 0.1 & [33] \\
\hline & $\operatorname{inv} E$ & $\begin{array}{l}\text { MP2-invE-F: CGATAGATGGCGAGAAATTATATCCCG } \\
\text { MP2-invE-R: CGATCAAGAATCCCTAACAGAAGAATCAC }\end{array}$ & 766 & 0.2 & [37] \\
\hline \multirow{3}{*}{ EAEC } & $\operatorname{aggR}$ & $\begin{array}{l}\text { MP2-aggR-F: ACGCAGAGTTGCCTGATAAAG } \\
\text { MP2-aggR-R: AATACAGAATCGTCAGCATCAGC }\end{array}$ & 400 & 0.2 & [32] \\
\hline & pic & $\begin{array}{l}\text { MP2-pic-F: AGCCGTTTCCGCAGAAGCC } \\
\text { MP2-pic-R: AAATGTCAGTGAACCGACGATTGG }\end{array}$ & 111 & 0.2 & [32] \\
\hline & $a s t A$ & $\begin{array}{l}\text { MP2-astA-F: TGCCATCAACACAGTATATCCG } \\
\text { MP2-astA-R: ACGGCTTTGTAGTCCTTCCAT }\end{array}$ & 102 & 0.4 & [32] \\
\hline
\end{tabular}


Table 1. Cont.

\begin{tabular}{|c|c|c|c|c|c|}
\hline Pathotypes & Target Genes & Primer Sequence $\left(5^{\prime}-3^{\prime}\right)$ & $\begin{array}{l}\text { Product } \\
\text { Size (bp) }\end{array}$ & $\begin{array}{l}\text { Concentration } \\
(\mu \mathrm{M})\end{array}$ & References \\
\hline \multirow{3}{*}{ ETEC } & elt & $\begin{array}{l}\text { MP2-LT-F: GAACAGGAGGTTTCTGCGTTAGGTG } \\
\text { MP2-LT-R: CTTTCAATGGCTTTTTTTTGGGAGTC }\end{array}$ & 655 & 0.1 & [32] \\
\hline & estIa & $\begin{array}{l}\text { MP4-STIa-F: CCTCTTTTAGYCAGACARCTGAATCASTTG } \\
\text { MP4-STIa-R: CAGGCAGGATTACAACAAAGTTCACAG }\end{array}$ & 157 & 0.4 & [32] \\
\hline & $e s t I b$ & $\begin{array}{l}\text { MP2-STI-F: TGTCTTTTTCACCTTTCGCTC } \\
\text { MP2-STI-R: CGGTACAAGCAGGATTACAACAC }\end{array}$ & 171 & 0.2 & [32] \\
\hline E. coli & uid $A$ & $\begin{array}{l}\text { MP2-uidA-F: ATGCCAGTCCAGCGTTTTTGC } \\
\text { MP2-uidA-R: AAAGTGTGGGTCAATAATCAGGAAGTG }\end{array}$ & 1487 & 0.2 & [32] \\
\hline
\end{tabular}

STEC, shiga toxin-producing Escherichia coli; EPEC, enteropathogenic E. coli; EIEC, enteroinvasive E. coli; EAEC, enteroaggregative E. coli; ETEC, enterotoxigenic E. coli.

\section{Results}

\subsection{Prevalence of the Escherichia coli Isolate According to the Effluent}

A total of 443 strains of $E$. coli was isolated in this study. The study showed that $E$. coli was present in $95 \%$ of cattle feces samples, $50 \%$ of slurry samples and $44.44 \%$ of manure in the composting process samples (Table 2).

Table 2. Prevalence of Escherichia coli in organic waste products from cattle markets.

\begin{tabular}{ccc}
\hline \multirow{2}{*}{ Type of Effluent } & \multicolumn{2}{c}{ Escherichia coli Isolates } \\
\cline { 2 - 3 } & Number & \% \\
\hline Manure in the composting process $(n=45)$ & 20 & 44.44 \\
Cattle feces $(n=340)$ & 323 & 95 \\
Slurry $(n=200)$ & 100 & 50 \\
Total $(n=585)$ & 443 & 75.72 \\
\hline
\end{tabular}

$\%=$ Prevalence of isolation.

\subsection{Diarrheagenic Virulence Gene Detection and DEC Prevalence}

Multiplex PCR assays were used to detect the selected virulence genes of diarrheagenic Escherichia coli among 443 Escherichia coli strains (Table 3).

DEC was detected in $10.76 \%$ of samples (Table 4$)$. A high rate $(9.91 \%)$ has been observed with ETEC. STEC and EAEC have been observed with the same rate (0.51\%). ETEC were detected in $12.64 \%$ of cattle feces, in $6.66 \%$ of manure in the composting process and in $5 \%$ of slurry. STEC were detected in $0.58 \%$ of cattle feces and $2.22 \%$ of manure in the composting process. EAEC was detected in $1 \%$ of slurry and $2.22 \%$ of manure in the composting process. ETEC strains contained estIa and/or estIb and/or elt (Table 3). Of the 58 ETEC, 10.34\% contained ast $A, 17.24 \%$ contained elt, 3.44\% contained estIa and $79.31 \%$ contained estIb.

The three positive STEC strains were isolated in $2.22 \%$ of manure and $0.58 \%$ of cattle feces (Table 4 ). All positive STEC strains contained the gene st $x_{1}$. One of them was positive for the st $x_{1}$ gene and the st $x_{2}$ gene, and the other was positive for the st $x_{2}$ gene (Table 3). EAEC was detected in $1 \%$ of slurry and $2.22 \%$ of manure in the composting process (Table 4 ). The two positive EAEC strains contained only the $\operatorname{ggg} R$ gene, and the third was positive only for the pic gene (Table 3).

The distribution of DEC according to the organic waste products of animals (Figure 2) shows that ETEC was present in all organic waste products (cattle fecal matter, manure in the composting process and slurry). STEC was present in manure in the composting process and cattle feces, and EAEC was present in slurry and manure in the composting process. 


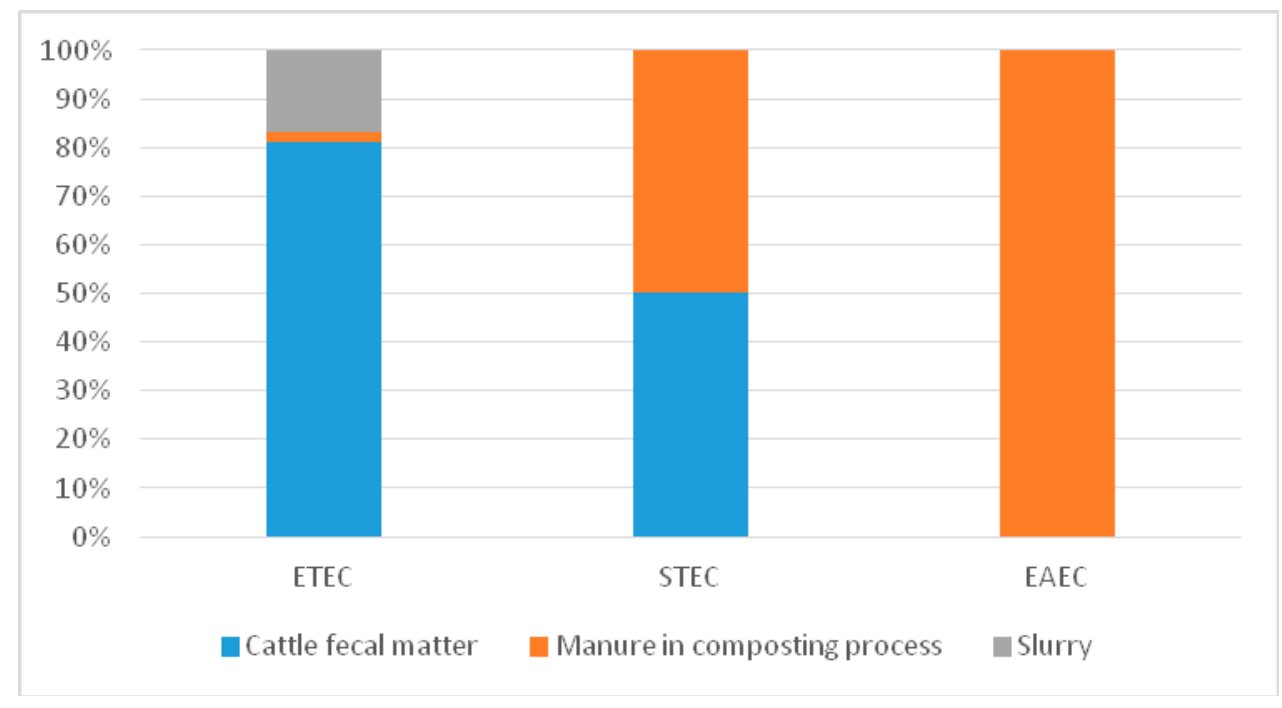

Figure 2. Distribution of diarrheagenic Escherichia coli (DEC) in organic waste products from the cattle markets. STEC: shiga toxin-producing E. coli; EAEC: enteroaggregative E. coli; ETEC: enterotoxigenic E. coli. 
Table 3. Virulence genes detected by 16-plex PCR in Escherichia coli isolates and in the six control strains.

\begin{tabular}{|c|c|c|c|c|c|c|c|c|c|c|c|c|c|c|c|c|}
\hline \multirow{2}{*}{$\begin{array}{c}\text { E. coli } \\
\text { Pathogroups }\end{array}$} & \multicolumn{16}{|c|}{ Virulence Gene } \\
\hline & eae & $e s C v$ & ent & $b f p$ & EHEC-hly & stx 1 & $s t x_{2}$ & ipaH & invE & aggR & Pic & astA & elt & estIa & $e s t I b$ & uidA \\
\hline STEC & + & + & + & - & + & + & + & - & - & - & - & - & - & - & - & + \\
\hline EPEC & + & + & + & - & - & - & - & - & - & - & - & - & - & - & - & - \\
\hline ETEC & - & - & - & - & - & - & - & - & - & - & - & + & + & - & + & + \\
\hline EAEC & - & - & - & - & - & - & - & - & - & + & + & + & - & - & - & + \\
\hline EIEC & - & - & - & - & - & - & - & - & - & + & + & - & - & - & - & + \\
\hline \multicolumn{17}{|c|}{ Number of virulence genes detected among Escherichia coli strains } \\
\hline STEC & - & - & - & - & - & 3 & 1 & - & - & - & - & - & - & - & - & 3 \\
\hline ETEC & - & - & - & - & - & - & - & - & - & - & - & 6 & 10 & 2 & 46 & 60 \\
\hline EAEC & - & - & - & - & - & - & - & - & - & 2 & 1 & - & - & - & - & 6 \\
\hline
\end{tabular}

+ = positive; - = none; EPEC: enteropathogenic E. coli; STEC: shiga toxin-producing E. coli; EHEC: enterohemorrhagic E. coli; EIEC: enteroinvasive E. coli; EAEC: enteroaggregative E. coli; ETEC: enterotoxigenic E. coli. 
Table 4. Prevalence of diarrheagenic Escherichia coli (DEC) in organic waste products from cattle markets.

\begin{tabular}{ccccc}
\hline \multirow{2}{*}{$\begin{array}{c}\text { E. coli } \\
\text { Pathogroups }\end{array}$} & $\begin{array}{c}\text { Cattle Feces } \\
(\boldsymbol{n}=\mathbf{3 4 0 )}\end{array}$ & $\begin{array}{c}\text { Slurry } \\
(\boldsymbol{n}=\mathbf{2 0 0})\end{array}$ & $\begin{array}{c}\text { Manure in the Composting Process } \\
(\boldsymbol{n}=\mathbf{4 5 )}\end{array}$ & $\begin{array}{c}\text { Total } \\
(\boldsymbol{n}=\mathbf{5 8 5})\end{array}$ \\
\hline Any DEC & $45(13.23 \%)$ & $13(6.5 \%)$ & $5(11.11 \%)$ & $63(10.76 \%)$ \\
STEC only & $2(0.58 \%)$ & 0 & $1(2.22 \%)$ & $3(0.51 \%)$ \\
ETEC only & $43(12.64 \%)$ & $11(5 \%)$ & $3(6.66 \%)$ & $58(9.91 \%)$ \\
EAEC only & 0 & $2(1 \%)$ & $1(2.22 \%)$ & $3(0.51 \%)$ \\
\hline
\end{tabular}

0: none; EPEC: enteropathogenic E. coli; STEC: shiga toxin-producing E. coli; EHEC: enterohemorrhagic E. coli; EIEC: enteroinvasive E. coli; EAEC: enteroaggregative E. coli; ETEC: enterotoxigenic E. coli; DEC = diarrheagenic Escherichia coli.

\section{Discussion}

The study investigated the occurrence of five major DEC pathogroups in 585 effluent samples from cattle markets by 16-plex PCR. To our knowledge, this study is the first of its kind in Burkina Faso. In the present study, DEC was detected in $10.76 \%$ of samples. In contrast, a lowest prevalence of DEC (7\%) was reported in Tanzania by Lupindu et al. (2014) from urban and peri urban livestock cattle feces and soil and water samples [38]. The prevalence of DEC found in this study is worrying because Burkina Faso is facing serious problems in wastewater management due to the demographic explosion and poor urban planning. In Burkina Faso wastewater, manure and slurry are used in crops without being treated beforehand [39]. These practices constitute a high risk for human health. In this study, ETEC $9.91 \%$ was the most commonly detected in all effluents purchased at the sites of study. In Brazil, a similar study of the enterovirulence potential of $E$. coli isolates from aquatic environments in Rio de Janeiro has shown that ETEC was present in 5\% of agricultural wastewaters [40].

ETEC strains can produce heat-stable (ST) and/or heat-labile (LT) enterotoxins [41]. There are two forms of ST, ST-I (STa) and ST-II (STb). ST-I has been associated with human infections, and ST-II has been associated with diarrhea in piglets. There are two variants of the human-associated ST-I: STIa (STIp, porcine variant) and STIb (STIh, human variant). The porcine and human variants were originally detected in ETEC strains of porcine and human origin, respectively. However, both ST-I variants can cause disease in humans [41,42]. In our study, we have detected the two variants of heat-stable (ST) enterotoxin. est $I b(80.70 \%)$ was found to be most prevalent, followed by elt $(17.54 \%)$, then estIa (3.50\%). Furthermore, Kagambèga et al. (2012) had found that estIb was most prevalent in food animals' feces [19]. These findings showed that the spreading of these strains in the environment through waste, effluents or cattle fecal matter constitutes a risk for human health. The persistence and ability of ETEC to survive in effluents like cattle effluent are mostly unknown. However, ETEC could survive for up to three months in freshwater [43] and was able to form biofilms in a wet environment [44].

STEC was detected at a prevalence rate of $0.51 \%$ and was present in $0.58 \%$ of cattle feces and $2.22 \%$ of manure. A similar study has been conducted by Dong et al. (2017) in Gyeonggi Province in Korea, where they obtained a $12.70 \%$ prevalence of STEC isolated form cattle farm samples, including feces, ground soil and water [45]. In contrast, Kabiru et al. (2015) have reported 1.37\% of STEC in effluent from the slaughterhouse spills in Nigeria [46]. These differences could be explained by the difference in sampling and/or the method used for the isolation of STEC. Indeed, studies have shown that young animals, such as calves and lambs, were the largest excretors of STEC [47], while in general, in Africa, cattle encountered at cattle markets for sale are mostly adults.

Shiga toxin (stx) is the main virulence trait of STEC. There are two types of shiga toxin, st $x_{1}$ and $s t x_{2}$, encoded by the genes $s t x_{1}$ and $s t x_{2}$. The mechanism of Stx delivery and trafficking through endothelial cells, such as renal cells, has been thoroughly described by [48].

In this study, the gene $s t x_{1}$ was present in all STEC isolates $(100 \%)$, and one of them $(33.33 \%)$ carried both forms of the stx virulence genes (st $x_{1}$ and $\left.s t x_{2}\right)$. In the Eastern Cape Province of South 
Africa, Iweriebor et al. (2015) obtained stx virulence genes in STEC strains isolated from dairy cattle farms, distributed as follows: $s t x_{1}(38.94 \%)$, st $x_{2}(40 \%)$ and two forms of stx virulence genes $s t x_{1}$, st $x_{2}$ $(9.47 \%)$ [49]. In Australia, st $x_{1}$ alone or in combination with st $x_{2}$ was found to be more prevalent than $s t x_{2}$ alone in STEC from humans, ruminant feces and meat [50]. The variability of stx gene in STEC from the same and or different countries could be explained by the fact that $E$. coli strains have the ability to lose or gain genes easily from their environment. This implies that the clinical signs of a diarrheal disease at STEC in Burkina Faso could arise under various manifestations.

EAEC was detected at a prevalence rate of $0.51 \%$ and has been detected in slurry $(1 \%)$ and manure in the composting process (2.22\%). A similar study of the slaughterhouses' effluent has been reported in the Zaria region, Nigeria [46]. EAEC strains were positive for $a g g R(66.66 \%)$ and the gene pic $(33.33 \%)$. Similar results were found in EAEC strains isolated in food animals and humans in Burkina Faso [51,52]. This result confirmed that food animals are the principal source of human DEC, which can be transmitted to humans in different ways.

According to the literature, EAEC are highly adapted to humans, suggesting that the human population is their reservoir [53,54]. Additionally, the isolation of EAEC from animals including cattle and abattoir effluent has been unsuccessfully attempted in different studies $[55,56]$.

The distribution of DEC according to the organic waste product of animal origin shows that cattle feces were contaminated by ETEC, STEC and EAEC. A previous study has shown that cattle feces may contain several DEC [19]. Manure in the composting process was contaminated by STEC and ETEC. STEC and ETEC have also been isolated from manure in the United States of America [56]. In general, the ability of these pathogens to adapt and persist in environments is inherent to E. coli [57]. Despite the low prevalence noted for these pathotypes, their presence in organic wastes reveals the risk for the population's health.

\section{Conclusions}

This study demonstrates that organic waste products from cattle markets in Ouagadougou are commonly contaminated by DEC, like ETEC, STEC and EAEC. The presence of these DEC in these effluents (cattle feces, manure in the composting process and slurry) shows that these effluents can constitute a means of human exposition and play an important role in the maintenance of the epidemiological cycle of diarrheal pathotypes of E. coli in Burkina Faso. This study shows the need for adequate management of the hygiene of these effluents before any form of recovery or any release of these effluents into the environment, to limit the spread of diarrheal strains of E. coli from animals to humans through the environment.

Acknowledgments: The authors thank "Cellule d'Appui à la Gestion des Collectivités Territoriale (CAGECT)" for the funding, as well as all the staff, and the Laboratoire de Biologie Moléculaire d'Epidémiologie et de surveillance des bactéries et virus transmis par les aliments (LaBESTA).

Author Contributions: Evariste Bako carried out strain isolation and characterization. Evariste Bako and Assèta Kagambèga drafted the manuscript. Nicolas Barro supervised and participated in the writing of the manuscript. All authors read, commented on and approved the final manuscript.

Conflicts of Interest: The authors declare no conflict of interest.

\section{References}

1. Graham, J.P.; Leibler, J.H.; Price, L.B.; Otte, J.M.; Pfeiffer, D.U.; Tiensin, T.; Silbergeld, E.K. The animal-human interface and infectious disease in industrial food animal production: Rethinking biosecurity and biocontainment. Public Health Rep. 2008, 123, 282-299. [CrossRef] [PubMed]

2. Islam, M.A.; Mondol, A.S.; de Boer, E.; Beumer, R.R.; Zwietering, M.H.; Talukder, K.A.; Heuvelink, A.E. Prevalence and genetic characterization of shiga toxin-producing Escherichia coli isolates from slaughtered animals in Bangladesh. Appl. Environ. Microbiol. 2008, 74, 5414-5421. [CrossRef] [PubMed] 
3. Rhoades, J.R.; Duffy, G.; Koutsoumanis, K. Prevalence and concentration of verocytotoxigenic Escherichia coli, Salmonella enterica and Listeria monocytogenes in the beef production chain: A review. Food Microbiol. 2009, 26, 357-376. [CrossRef] [PubMed]

4. Jenkins, C.; Lawson, A.J.; Cheasty, T.; Willshaw, G.A.; Wright, P.; Dougan, G.; Frankel, G.; Smith, H.R. Subtyping intimin genes from enteropathogenic Escherichia coli associated with outbreaks and sporadic cases in the United Kingdom and Eire. Mol. Cell. Probes 2003, 17, 149-156. [CrossRef]

5. Levine, M.M. Escherichia coli that cause Diarrhea: Enterotoxigenic, Enteropathogenic, Enteroinvasive, Enterohemorrhagic, and Enteroadherent. J. Infect. Dis. 1987, 3, 377-381. [CrossRef]

6. Nataro, J.P.; Kaper, J.B. Diarrheagenic Escherichia coli. Clin. Microbiol. Rev. 1998, 11, 142-201. [PubMed]

7. Schmidt, H.; Beutin, L.; Karch, H. Molecular analysis of the plasmid-encoded hemolysin of Escherichia coli O157:H7 strain EDL 933. Infect. Immun. 1995, 63, 1055-1061. [PubMed]

8. Paton, A.W.; Paton, J.C. Detection and characterization of Shiga toxigenic Escherichia coli by using multiplex PCR assays for $s t x_{1}$, stx 2 , eaeA, enterohemorrhagic E. coli hlyA, rfbO111, and rfbO157. J. Clin. Microbiol. 1998, 36, 598-602. [PubMed]

9. Schmidt, H.B.; Karch, L.; LEE, H. Ways: Tales of EPEC, ATEC and EHEC. Cell. Microbiol. 2010, 12, $1544-1552$. [CrossRef] [PubMed]

10. Trabulsi, L.; Keller, R.; Tardelli, R.; Gomes, T.A. Typical and atypical enteropathogenic Escherichia coli. Emerg. Infect. Dis. 2002, 8, 508-513. [CrossRef] [PubMed]

11. Kaper, J.B.; Nataro, J.P.; Mobley, H.L. Pathogenic Escherichia coli. Nat. Rev. Microbiol. 2004, 2, $123-1240$. [CrossRef] [PubMed]

12. Lan, R.; Alles, M.C.; Donohoe, K.; Martinez, M.B.; Reeves, P.R. Molecular evolutionary relationships of enteroinvasive Escherichia coli and Shigella spp. Infect. Immun. 2004, 72, 5080-5088. [CrossRef] [PubMed]

13. Huang, D.B.; Okhuysen, P.C.; Jiang, Z.D.; Du Pont, H.L. Enteroaggregative Escherichia coli: An emerging enteric pathogen. Am. J. Gastroenterol. 2004, 99, 383-389. [CrossRef] [PubMed]

14. Comité Permanent Inter-Etats de Lutte contre la Sècheresse dans le Sahel (CILSS). L'élevage au Sahel et en Afrique de L'Ouest, in 26ème Réunion Annuelle du Réseau de Prévention des Crises Alimentaires (RPCA) 2010; CILSS: Accra, Ghana, 2010; p. 10.

15. Comité Permanent Inter-Etats de Lutte Contre la Sècheresse dans le Sahel (CILSS). Appuis Institutionnels à la Mise en CEuvre de la Stratégie Régionale de Renforcement des Services Vétérinaires et Préparation à L'accès des Viandes Sahéliennes Aux Marchés des Pays d'Afrique du Nord; CILSS: Ouagadougou, Burkina Faso, 2010; p. 131.

16. Jones, P.W. Animal health todayproblems of large livestock units. Disease hazards associated with slurry disposal. Br. Vet. J. 1980, 136, 529-540. [PubMed]

17. Woolcock, J.B. Microbiology Of Animals And Animal Products; Elsevier Science Publishing Company, Inc.: New York, NY, USA, 1991.

18. Mechie, S.C.; Chapman, P.A.; Siddons, C.A. A fifteen month study of Escherichia coli O157:H7 in a dairy herd. Epidemiol. Infect. 1997, 118, 17-25. [CrossRef] [PubMed]

19. Kagambèga, A.; Martikainen, O.; Siitonen, A.; Traoré, A.S.; Barro, N.; Haukka, K. Prevalence of diarrheagenic Escherichia coli virulence genes in the feces of slaughtered cattle, chickens, and pigs in Burkina Faso. Microbiologyopen 2012, 3, 276-284. [CrossRef] [PubMed]

20. Nitiema, L.W.; Nordgren, J.; Ouermi, D.; Dianou, D.; Traore, A.S.; Svensson, L.; Simpore, J. Burden of rotavirus and other enteropathogens among children with diarrhea in Burkina Faso. Int. J. Infect. Dis. 2011, 15, e646-e652. [CrossRef] [PubMed]

21. Okeke, I.N. Diarrheagenic Escherichia coli in sub-Saharan Africa: Status, uncertainties and necessities. J. Infect. Dev. Ctries. 2009, 11, 817-842. [CrossRef]

22. Bonkoungou, I.J.O.; Lienemann, T.; Martikainen, O.; Dembelé, R.; Sanou, I.; Traoré, A.S.; Barro, N. Diarrhoeagenic Escherichia coli detected by 16-plex PCR in children with and without diarrhoea in Burkina Faso. Clin. Microbiol. Infect. 2012, 9, 901-906. [CrossRef] [PubMed]

23. Centers for Disease Control and Prevention (CDC). Diarrhea: Common Illness, Global Killer; CDC: Atlanta, GA, USA, 2016; p. 4.

24. United Nations Children's Fund (UNICEF). Pneumonia And Diarrhoea: Tackling the Deadliest Diseases for the World's Poortes Children; UNICEF: New York City, NY, USA, 2012; p. 77.

25. United Nations Children's Fund (UNICEF); World Health Organization (WHO). Diarrhoea: Why Children Are Still Dying and What Can Be Done; UNICEF; WHO: New York City, NY, USA, 2009; p. 68. 
26. Strauch, D. Livestock manure as a vector for infectious agents. Dtsch. Tieraerztl. Wochenschr. 1991, 98, 265-268.

27. Tauxe, R. Emerging foodborne diseases: An evolving public health challenge. Emerg. Infect. Dis. 1997, 3, 425-434. [CrossRef] [PubMed]

28. Lambertini, E.; Karns, J.S.; Van Kessel, J.A.; Cao, H.; Schukken, Y.H.; Wolfgang, D.R.; Smith, J.M.; Pradhan, A.K. Dynamics of Escherichia coli Virulence Factors in Dairy Herds and Farm Environments in a Longitudinal Study in the United States. Appl. Environ. Microbiol. 2015, 81, 4477-4488. [CrossRef] [PubMed]

29. Cooley, M.; Carychao, D.; Crawford-Miksza, L.; Jay, M.T.; Myers, C.; Rose, C.; Keys, C.; Farrar, J.; Mandrell, R.E. Incidence and tracking of Escherichia coli O157:H7 in a major produce production region in California. PLoS ONE 2007, 2, e1159. [CrossRef] [PubMed]

30. Fremaux, B.; Prigent-Combaret, C.; Vernozy-Rozand, C. Long-term survival of Shiga toxin-producing Escherichia coli in cattle efuents and environment: An updated review. Vet. Microbiol. 2008, 1, 1-18. [CrossRef] [PubMed]

31. Cheesbrough, M. Microbiological tests. In Districts Laboratory Practice in Tropical Countries, C; Cambridge University Press: Cambridge, UK, 2006; pp. 9-267.

32. Müller, D.; Greune, L.; Heusipp, G.; Karch, H.; Fruth, A.T.H.; Schmidt, H.A. Identification of unconventional intestinal pathogenic Escherichia coli isolates expressing intermediate virulence factor profiles by using a novel single-step multiplex PCR. Appl. Environ. Microbiol. 2007, 73, 3380-3390. [CrossRef] [PubMed]

33. Antikainen, J.; Tarkka, E.; Haukka, K.; Siitonen, A.; Vaara, M.; Kirveskari, J. New 16-plex PCR method for rapid detection of diarrheagenic Escherichia coli directly from stool samples. Eur. J. Clin. Microbiol. Infect. Dis. 2009, 28, 899-908. [CrossRef] [PubMed]

34. Baldini, M.M.; Kaper, J.B.; Levine, M.M.; Candy, D.C.M.H. Plasmid-mediated adhesion in enteropathogenic Escherichia coli. J. Pediatr. Gastroenterol. Nutr. 1983, 2, 534-538. [CrossRef] [PubMed]

35. Keskima, K.M.; Mattila, L.; Peltola, H.S.A. Prevalence of diarrheagenic Escherichia coli in Finns with or without diarrhea during a round-the-world trip. J. Clin. Microbiol. 2000, 38, 4425-4429.

36. Vidal, M.; Kruger, E.; Duran, C.; Lagos, R.; Levine, M.; Prado, V.; Toro, C.; Vidal, R. Single Multiplex PCR Assay To Identify Simultaneously the Six Categories of Diarrheagenic Escherichia coli Associated with Enteric. Infect. J. Clin. Microbiol. 2005, 43, 5362-5365. [CrossRef] [PubMed]

37. Brandal, L.T.; Lindstedt, B.A.; Aas, L.; Stavnes, T.L.; Lassen, J.K.G. Octaplex PCR and fluorescence-based capillary electrophoresis for identification of human diarrheagenic Escherichia coli and Shigella spp. J. Microbiol. Methods 2007, 68, 331-341. [CrossRef] [PubMed]

38. Lupindu, A.M.; Olsen, J.E.; Ngowi, H.A.; Msoffe, P.L.M.; Mtambo, M.M.; Scheutz, F.; Dalsgaard, A. Occurrence and Characterization of Shiga Toxin-Producing Escherichia coli O157:H7 and other Non-Sorbitol Fermenting E. coli in Cattle and Humans in Urban Areas of Morogoro, Tanzania. Vector Borne Zoonotic Dis. 2014, 7, 503-510. [CrossRef] [PubMed]

39. Traore, O.; Nyholm, O.; Siitonen, A.; Bonkoungou, I.O.J.; Traore, A.S.; Barro, N.; Haukka, K. Prevalence and diversity of Salmonella enterica in water, fish and lettuce in Ouagadougou, Burkina Faso. BMC Microbiol. 2015, 15, 151. [CrossRef] [PubMed]

40. Rebello, R.C.; Regua-Mangia, A.H. Potential enterovirulence and antimicrobial resistance in Escherichia coli isolates from aquatic environments in Rio de Janeiro, Brazil. Sci. Total Environ. 2014, 490, 19-27. [CrossRef] [PubMed]

41. Sjöling, A.; Wiklund, G.; Savarino, S.J.; Cohen, D.I.S.A.M. Comparative analyses of phenotypic and genotypic methods for detection of enterotoxigenic Escherichia coli toxins and colonization factors. J. Clin. Microbiol. 2007, 45, 3295-3301. [CrossRef] [PubMed]

42. Lothigius, A.; Söling, A.; Svennerholm, A.M.B.I. Survival and gene expression of enterotoxigenic Escherichia coli during long-term incubation in sea water and fresh water. J. Appl. Microbiol. 2010, 108, 1441-1449. [CrossRef] [PubMed]

43. Ahmed, W.; Sritharan, T.; Palmer, A.; Sidhu, J.P.S.; Tozea, S. Evaluation of bovine feces-associated microbial source tracking markers and their correlations with fecal indicators and zoonotic pathogens in a Brisbane, Australia, reservoir. Appl. Environ. Microbiol. 2013, 8, 2682-2691. [CrossRef] [PubMed] 
44. Dong, H.J.; Lee, S.; Kim, W.; An, J.U.; Kim, J.; Kim, D.; Cho, S. Prevalence, virulence potential, and pulsed-field gel electrophoresis profiling of Shiga toxin-producing Escherichia coli strains from cattle. Gut Pathog. 2017, 9, 22. [CrossRef] [PubMed]

45. Kabiru, L.M.; Bello, M.; Kabir, J.; Grande, L.; Morabito, S. Detection of pathogenic Escherichia coli in samples collected at an abattoir in Zaria, Nigeria and at different points in the surrounding environment. Int. J. Environ. Res. Public Health 2015, 12, 679-691. [CrossRef] [PubMed]

46. Robinson, S.E.; Wright, E.J.; Hart, C.A.; Bennett, M.; French, P. Intermittent and persistent shedding of Escherichia coli $\mathrm{O} 157$ in cohorts of naturally infected calves. J. Appl. Microbiol. 2004, 97, 1045-1053. [CrossRef] [PubMed]

47. Lee, M.S.; Cherla, R.P.T.V. Shiga toxins: Intracellular trafficking to the ER leading to activation of host cell stress responses. Toxins 2010, 2, 1515-1535. [CrossRef] [PubMed]

48. Iweriebor, B.C.; Iwu, C.J.; Obi, L.C.; Nwodo, U.U.; Okoh, A.I. Multiple antibiotic resistances among Shiga toxin producing Escherichia coli O157 in feces of dairy cattle farms in Eastern Cape of South Africa. BMC Microbiol. 2015, 15, 213. [CrossRef] [PubMed]

49. Brett, K.N.; Ramachandran, V.; Hornitzky, M.A.; Bettelheim, K.A.; Walker, M.J.D.S. Stx 1 is the most common Shiga toxin 1 subtype among Shiga toxin-producing Escherichia coli isolates from sheep but not among isolates from cattle. J. Clin. Microbiol. 2003, 41, 926-936. [CrossRef] [PubMed]

50. Kagambèga, A.; Martikainen, O.; Lienemann, T.; Siitonen, A.; Traoré, A.S.; Barro, N.; Haukka, K. Diarrheagenic Escherichia coli detected by 16-plex PCR in raw meat and beef intestines sold at local markets in Ouagadougou, Burkina Faso. Int. J. Food Microbiol. 2012, 1-2, 154-158. [CrossRef] [PubMed]

51. Bonkoungou, I.J.O.; Lienemann, T.; Martikainen, O.; Dembele, R.; Sanou, I.; Traore, A.S.; Siitonen, A.; Barro, N.; Haukka, K. Detection of diarrhoeagenic Escherichia coli by 16-plex PCR from young children in urban and rural Burkina Faso. Clin. Microbiol. Infect. 2012, 18, 901-906. [CrossRef] [PubMed]

52. Harrington, S.M.; Dudley, E.G.N.J. Pathogenesis of enteroaggregative Escherichia coli infection. FEMS Microbiol. Lett. 2006, 254, 12-18. [CrossRef] [PubMed]

53. Uber, A.P.; Trabulsi, L.R.; Irino, K.; Beutin, L.; Ghilardi, A.C.; Gomes, T.A.; Liberatore, A.M.; de Castro, A.F.; Elias, W.P. Enteroaggregative Escherichia coli from humans and animals differ in major phenotypical traits and virulence genes. FEMS Microbiol. Lett. 2006, 256, 251-257. [CrossRef] [PubMed]

54. Auvray, F.; Dilasser, F.; Bibbal, D.; Kerouredan, M.; Oswald, E.; Brugere, H. French cattle is not a reservoir of the highly virulent enteroaggregative Shiga toxin-producing Escherichia coli of serotype O104: H4. Vet. Microbiol. 2012, 158, 443-445. [CrossRef] [PubMed]

55. Bibbal, D.; Kerouredan, M.; Loukiadis, E.; Scheutz, F.; Oswald, E.; Brugere, H. Slaughterhouse effluent discharges into rivers not responsible for environmental occurrence of enteroaggregative Escherichia coli. Vet. Microbiol. 2014, 168, 451-454. [CrossRef] [PubMed]

56. Heringa, S.; Kim, J.; Shepherd, M.W.; Singh, R.; Jiang, X. The presence of antibiotic resistance andintegrons in Escherichia coli isolated from compost. Foodborne Pathog. Dis. 2010, 7, 1297-1304. [CrossRef] [PubMed]

57. Na, H.; Miyanaga, K.; Unno, H.; Tanji, Y. The survival response of Escherichia coli K12 in a natural environment. Appl. Microbiol. Biotechnol. 2006, 72, 386-392. [CrossRef] [PubMed]

(C) 2017 by the authors. Licensee MDPI, Basel, Switzerland. This article is an open access article distributed under the terms and conditions of the Creative Commons Attribution (CC BY) license (http://creativecommons.org/licenses/by/4.0/). 